\title{
The Role of the Just in Time Method in Cost Efficiency in the Provision of Raw Materials in PT Suzuki Indomobil Motor Division Die Casting
}

\author{
Agustian Burda*, Farmansjah Maliki \\ Department of Management \\ Sekolah Tinggi Ilmu Ekonomi Indonesia \\ Jakarta, Indonesia \\ *agustian_burda@stei.ac.id,farmansjah@stei.ac.id
}

\begin{abstract}
As a system of continuous improvement Just In Time (JIT) concentrates on eliminating the vanity and variability that gives rise to that vanity. Variability is "any deviation from the optimal process that delivers the perfect product on time at all times. Inventory saves variability, the more variability in the system the smaller the vanity that occurs. Although there are several causes for variability, it is often revealed and seen when there is an inventory, because inventory hides the problem. Just In Time's philosophy of continuous improvement eliminates variability, eliminating this variability makes it possible to move good and regular raw materials when they are needed without having to be stored in inventory. JIT decreases raw materials during production as long as the ordered supply arrives so that vanity decreases and the value of the product at each stage improves. With the concept of "pull system" that produces one unit and then pulled to the place that needs it when needed. This concept is used in the scope of the production process which will soon be carried out with its suppliers. By pulling raw materials through this system in small lot sizes in accordance with the required amount, the pile of inventory is erased which conceals the problem. With the elimination of supplies, investment in inventory and manufacturing cycles decreases or the time between when raw materials are received and when finished goods leave the production facility.
\end{abstract}

Keywords: Just In Time (JIT), overcomes waste, variability

\section{INTRODUCTION}

Just in time has two strategic objectives, namely increasing revenue and increasing the company's position in competition. Both of these goals can be achieved by controlling costs, increasing shipping performance and improving quality. Just in time offers increased cost efficiency and flexibility in responding to declining corporate profit demands as a result of high costs and shrinking market share.

Waste will also have an impact on the quality and delivery of useless operating goods which have a tendency to worsen quality, namely defects, scrap and rework. Unfavourable processes in a series of businesses will also increase lead times, resulting in late submission. Poor quality and delivery will result in decreased level of consumer satisfaction.
Reducing waste is the main driver of just in time, this is also the main goal of all companies, whether users are just in time or not. Just in time is more than just an inventory management system. Inventory which includes resources, such as funds, space, and labour is seen as a waste. In it hidden inefficiencies in production and increasing complexity of the information system of a company. Although just in time is more than just focusing on inventory management, inventory control is very important. Company research conducted by the author on the company, found that the company has implemented a just in time method to improve the quality of production on an ongoing basis, so that the expected efficiency and productivity are achieved as they should.

Based on the above facts, the authors are compelled to conduct research to take the title "The Role of the Just in Time Method in Cost Efficiency in the Provision of Raw Materials in PT Suzuki Indomobil Motor Division Die Casting."

\section{THEORETICAL FRAMEWORK}

Just In Time has become a necessity for every assembling company. Especially if the price of raw materials is high, it does not allow companies to pile up raw materials. Apart from the high total cost of raw materials, it will also cause the quality of raw materials to be stacked to decrease. As well as increasing costs to maintain raw materials that have not been produced to be increased. Besides that just in time causes a reduction in the time interval from the start of the goods produced until the goods are finished and sent to the customer [1].

An efficient and effective production planning and inventory management strategy is needed to overcome these problems, namely by applying the Just In Time (JIT) method. Just In Time (JIT) is a philosophy, especially in the production process, which aims to eliminate wastes. Waste is defined as anything that does not add value to the product or service offered to consumers, everything that includes material, space, time, energy, systems and people involved in the conversion process. This JIT system can overcome the problem of overstock or understock which can result in losses for the 
Information:

$\mathrm{r}_{\mathrm{s}} \quad:$ Spearman correlation coefficient

$\sum x^{2} \quad$ : Just In Time Variable with Correlation for the same number.

$\sum y^{2} \quad$ : Variable cost efficiency of raw material inventory with the same correction. flexibility, precise delivery time, guaranteed quality, and minimum cost of production. This kind of manufacturing strategy will be very beneficial for companies that experience demand patterns whose requirements change easily such as volume, quality, design, and other product attributes [1].

\section{METHODS}

The research method used in this study is descriptive, which is a research method that aims to obtain data that describes the state of a company and conduct an analysis of things that will be examined to get conclusions.

Then according to Sugiyono [3] that descriptive research is research conducted to determine the value of an independent variable, either one or more variables without making comparisons, or connecting with other variables.

\section{A. Data Processing Techniques}

Data obtained through the questionnaire was processed by Rank Spearman statistical analysis, in its analysis, namely:

\section{B. Correlation Coefficient Analysis}

This was done to test the relationship between the independent variables using the Spearman Rank. If there are no twin scores, according to Sugiyono [3] with the formula:

$$
\mathrm{r}_{\mathrm{S}}=1-\frac{6 \sum_{\mathrm{i}=1}^{\mathrm{N}} \mathrm{di}^{2}}{\mathrm{~N}^{3}-\mathrm{N}}
$$

The Spearman correlation [4] denoted by the formula is:

\section{Rs : Spearman's Rank correlation coefficient.}

$\mathrm{N}$ : number of respondents.

at 2 : the difference between rank $X$ and rank squared.

If there are twin numbers in variable $\mathrm{X}$ and $\mathrm{Y}$, then the Spearman rank formula is used as follows:

$$
r_{s}=\frac{\sum x^{2}+\sum y^{2}+\sum d^{2}}{\sqrt[2]{\sum x^{2} \sum y^{2}}}
$$

Where:

$$
\begin{aligned}
& \sum \mathrm{x}^{2}=\frac{\mathrm{N}^{3}-\mathrm{N}}{12}-\sum \mathrm{T} \mathrm{x} \\
& \sum \mathrm{y}^{2}=\frac{\mathrm{N}^{3}-\mathrm{N}}{12}-\sum \mathrm{Ty} \\
& \mathrm{T}=\frac{\mathrm{T}^{3}-\mathrm{T}}{12}
\end{aligned}
$$
$\mathrm{N} \quad$ : Number of samples.
Q : Correction Factor
$\sum \mathrm{di}^{2} \quad$ : The sum of the squares of the rank difference
T : Number of twins

To see the interpretation of rs the Correlation Coefficient interpretation table is used as shown in table I below

TABLE I. INTERPRETATION OF CORRELATION COEFFICIENTS [4]

\begin{tabular}{|l|l|}
\hline \multicolumn{1}{|c|}{ Interval Questionnaire } & \multicolumn{1}{c|}{ Level Relationship } \\
\hline $0,00-0,19$ & Very low \\
\hline $0,20-0,39$ & Low \\
\hline $0,40-0,59$ & Is \\
\hline $0,60-0,79$ & Strong \\
\hline $0,80-1,00$ & Very strong \\
\hline
\end{tabular}

\section{Test of Significance}

This is done to find out whether the hypothesis is accepted or rejected by finding $t$ arithmetic with the formula:

$$
\begin{aligned}
& \mathrm{t}=[\mathrm{r}]] \mathrm{s} \sqrt{ }(\mathrm{n}-2) \\
& \sqrt{ }(1-\mathrm{r}) \mathrm{s}^{\wedge} 2
\end{aligned}
$$

Where:

$$
\begin{array}{ll}
\mathrm{N} & \text { : number of samples } \\
\mathrm{rs} & \text { : correlation coefficient }
\end{array}
$$

The criteria for acceptance or rejection of the hypothesis test are:

- Rejection area if tcount $>$ ttable.

- The reception area if tcount <ttable.

- Analysis of the coefficient of determination.

This was done to determine the amount of the contribution of accounting information systems to the effectiveness of internal control of raw material inventory by the formula:

$$
\mathrm{Kd}=\mathrm{rs} 2 \times 100 \% .
$$

With a significant level of confidence $95 \%(1-\alpha)$ selected using $\alpha=0.05$. This figure was chosen by the company because it was considered strong enough to represent the influence between variables.

\section{RESULTS AND DISCUSSION}

\section{A. Just In Time Method at PT. Suzuki Indomobil Motor Die Casting Division}

The Just In Time Method has been running since 2007 because of the policies of PT. Suzuki Indomobil Die Casting Division to meet customer demands in order to meet the specification requirements to become a supplier of aluminium 
parts for customer. In carrying out the just in time method, the management creates one section, where this section is led by the section head and consists of representatives from each section. Like the section.

Each section will be taught about this just time and about kanban which is a tool used in just in time through training. Each representative is the party that will run the system just in time, especially kanban in each section.

\section{B. Cost Efficiency of Raw Material Inventory at PT. Suzuki Indomobil Motor Die Casting Division}

In an effort to create cost-efficient inventory of raw materials. Suzuki Indomobil Motor has done a variety of ways. Following are the ways. PT. Suzuki Indomobil Motor Die Casting division Train workers to become more skilled at eliminating errors (waste):

- Improve the quality of raw materials

- Reducing the number of assets invested in the procurement of raw materials
Of the three ways carried out by PT. Suzuki Indomobil Motor Die Casting division two of which were carried out through the application of the just in time method. The first way is done through training - both skills in the form of abilities related to work, and training in the form of communication skills (cooperation). And the company also cultivates an efficient work ethic.

The second and third ways companies do it by applying the just in time method. Because of the characteristics of just in time that aims to maintain the quality of the results of high production, the company can benefit from the use of just in time in the role of investment for supply costs. From the use of the just in time method, it can be seen the difference that occurs during the six previous periods after the use of the just in time method.

The first period before the use of the just in time method is January 2017, the second period in February 2017, the third period in March 2017, the fourth period in April 2017, the fifth period in May, the six period in May June 2017.

TABLE II. COMPARISON BETWEEN JIT AND CONVENTIONAL

\begin{tabular}{|c|c|c|c|c|c|c|}
\hline & Jan & Feb & Mar & Apr & Mei & June \\
\hline \multicolumn{7}{|c|}{ Conventional } \\
\hline Direct raw material & 224.592 .484 & 223.485 .672 & 203.563 .056 & 185.741 .124 & 173.746 .896 & 149.622 .912 \\
\hline Raw material is available & 8.784 .315 .084 & 7.451 .239 .008 & 7.304 .981 .788 & 6.607 .057 .764 & 4.753 .825 .304 & 4.694 .870 .624 \\
\hline Raw material used & 9.008 .907 .568 & 7.674.724.680 & 7.508.544.844 & 6.792 .798 .888 & 4.927.572.200 & 4.844.493.536 \\
\hline Direct labor & 7.000 .000 & 7.000 .000 & 7.000 .000 & 7.000 .000 & 7.000 .000 & 7.000 .000 \\
\hline Insurance fee & 22.522 .269 & 19.186 .812 & 19.186 .812 & 19.186 .812 & 19.186 .812 & 19.186 .812 \\
\hline Operating costs & 900.891 & 767.472 & 750.854 & 679.276 & 492.757 & 484.449 \\
\hline FOH variabel & 23.423.160 & 19.954 .284 & 19.937 .666 & 19.866 .088 & 19.679 .569 & 19.671.261 \\
\hline Forclip Accumulation & 5.833 .333 & 5.833 .333 & 5.833 .333 & 5.833 .333 & 5.833 .333 & 5.833 .333 \\
\hline Warehouse accumulation & 12.000 .000 & 12.000 .000 & 12.000 .000 & 12.000 .000 & 12.000 .000 & 12.000 .000 \\
\hline Indirect labor & 2.300 .000 & 2.300 .000 & 2.300 .000 & 2.300 .000 & 2.300 .000 & 2.300 .000 \\
\hline Fixed costs FOH & 20.133 .333 & 20.133.333 & 20.133.333 & 20.133.333 & 20.133.333 & 20.133.333 \\
\hline Total inventory cost & 9.059.464.061 & 7.721.812.297 & 7.555.615.843 & 6.839.798.309 & 4.974.385.102 & 4.891.298.130 \\
\hline \multicolumn{7}{|c|}{ Just In Time } \\
\hline \multicolumn{7}{|l|}{ Raw material is available } \\
\hline Raw material used & 8.783.208.272 & 7.431.316.472 & 7.304.981.788 & 6.595.063.536 & 4.729.701.320 & 4.663.021.544 \\
\hline Direct labor & 14.000 .000 & 14.000 .000 & 14.000 .000 & 14.000 .000 & 14.000 .000 & 14.000 .000 \\
\hline Insurance fee & 21.958 .021 & 18.578 .291 & 18.262 .454 & 16.487 .659 & 11.824 .253 & 11.657 .554 \\
\hline Warehouse accumulation & 1.200 .000 & 1.200 .000 & 1.200 .000 & 1.200 .000 & 1.200 .000 & 1.200 .000 \\
\hline Operating costs & 878.321 & 743.132 & 730.498 & 659.506 & 472.970 & 466.302 \\
\hline FOH variable & 24.036 .342 & 20.521 .423 & 20.192 .952 & 18.347 .165 & 13.497.223 & 13.323.856 \\
\hline Forclip Accumulation & 5.833 .333 & 5.833 .333 & 5.833 .333 & 5.833 .333 & 5.833 .333 & 5.833 .333 \\
\hline Total inventory cost & 8.827.077.947 & 7.471.671.228 & 7.345.008.073 & 6.633.244.034 & 4.763.031.876 & 4.696.178.733 \\
\hline Difference in Total Inventory Fees & \multirow{2}{*}{232.386 .114} & \multirow{2}{*}{ 250.141.069 } & \multirow{2}{*}{210.607 .770} & \multirow{2}{*}{206.554 .275} & \multirow{2}{*}{ 211.353.226 } & \multirow{2}{*}{ 195.119.397 } \\
\hline Conventional-JIT & & & & & & \\
\hline
\end{tabular}

From the table above it can be seen the differences in inventory costs before adopting the just in time system and after adopting the just in time system. From the comparison between period I (January) after and before just in time there was a decrease in inventory costs Rp.232,386,114. cost reduction in period II (February) after and before just in time there was a decrease in inventory costs by Rp.250,141,069 a decrease in costs in period III (March) after and before just in time there was a decrease in inventory costs by Rp.210,607,770. cost reduction in period IV (April) after and before million in time there was a decrease in inventory costs by Rp.206,554,275. cost reduction in period V (May) after and 


$$
T_{x}=T_{y}=\frac{t^{3}-t}{12}
$$

a decrease in inventory costs by Rp.211,353,226. cost reduction in the period VI (June) after and before just in time there was a decrease in inventory costs by Rp.195,119,397.

\section{Hypothesis Examiners}

To find out the cost efficiency of the supply of raw materials in connection with the existence of the just in time method, a questionnaire was arranged for 20 respondents. Of the 20 respondents who filled out and returned the results as many as 20 respondents. The questionnaire was distributed to the purchasing department, the warehouse section, and the Die Casting section.

\section{Correlation Coefficient Analysis}

This analysis was conducted to determine the strength of the relationship between variable $\mathrm{X}$ and variable $\mathrm{Y}$. For this analysis, based on attachments and appendix 6 p.86 (variable score y) then arrange table 3 to find out the differences between rank $\mathrm{x}$ and rank $\mathrm{y}$ in order to make it easier in statistical calculations with using the RANK SPEARMAN formula, as follows:

TABLE III. RANKING Of JUST In TIME METHODS IN EFFICIENCY RAW MATERIAL INVENTORY COSTS

\begin{tabular}{|l|l|l|l|l|l|l|}
\hline No & Score X & Score $\mathbf{Y}$ & $\mathbf{R a n k} \mathbf{X}$ & $\mathbf{R a n k} \mathbf{Y}$ & \multicolumn{1}{|c|}{$\mathbf{d i}$} & \multicolumn{1}{c|}{$\mathbf{d i}^{\mathbf{2}}$} \\
\hline 1 & 39 & 39 & 16 & 9.5 & 6.5 & 42.25 \\
\hline 2 & 44 & 38 & 3 & 12.5 & -9.5 & 90.25 \\
\hline 3 & 42 & 42 & 6.5 & 3 & 3.5 & 12.25 \\
\hline 4 & 42 & 38 & 6.5 & 12.5 & -6 & 36 \\
\hline 5 & 38 & 36 & 18.5 & 17 & 1.5 & 2.25 \\
\hline 6 & 40 & 37 & 12 & 15.5 & -3.5 & 12.25 \\
\hline 7 & 38 & 34 & 18.5 & 19 & -0.5 & 0.25 \\
\hline 8 & 44 & 41 & 3 & 4.5 & -1.5 & 2.25 \\
\hline 9 & 47 & 46 & 1 & 1 & 0 & 0 \\
\hline 10 & 40 & 38 & 12 & 12.5 & -0.5 & 0.25 \\
\hline 11 & 44 & 40 & 3 & 7 & -4 & 16 \\
\hline 12 & 34 & 35 & 20 & 18 & 2 & 4 \\
\hline 13 & 41 & 32 & 8.5 & 20 & -11.5 & 132.25 \\
\hline 14 & 41 & 38 & 8.5 & 12.5 & -4 & 16 \\
\hline 15 & 40 & 37 & 12 & 15.5 & -3.5 & 12.25 \\
\hline 16 & 39 & 40 & 16 & 7 & 9 & 81 \\
\hline 17 & 39 & 41 & 16 & 4.5 & 11.5 & 132.25 \\
\hline 18 & 40 & 40 & 12 & 7 & 5 & 25 \\
\hline 19 & 40 & 39 & 12 & 9.5 & 2.5 & 6.25 \\
\hline 20 & 43 & 43 & 5 & 2 & 3 & 9 \\
\hline$\sum$ & 815 & 774 & & & & 632 \\
\hline
\end{tabular}

Source: answers to questionnaires from respondents (processed by the author)

Since there are twin values, to calculate the value of rs, calculate the correction for the $\mathrm{X}$ variable and the $\mathrm{Y}$ variable on the basis of:

$$
r_{s}=\frac{\sum X^{2}+\sum Y^{2}+\sum d i^{2}}{\sqrt[2]{\sum X^{2} \sum Y^{2}}}
$$

Where:

$$
\begin{aligned}
& \sum X^{2}=\frac{N^{3}-N}{12}-\sum T X \\
& \sum Y^{2}=\frac{N^{3}-N}{12}-\sum T y
\end{aligned}
$$

To calculate $\sum \mathrm{X} 2$ it is first calculated $\sum \mathrm{TX}$ as shown in table IV below:

TABLE IV. VARIABLE X SCORE FOR TWINS

\begin{tabular}{|l|l|l|}
\hline $\begin{array}{c}\text { Var X scores } \\
\text { are twins }\end{array}$ & $\begin{array}{c}\text { Number of Var X } \\
\text { scores for twins (t) }\end{array}$ & $T_{x}=\frac{t^{3}-t}{12}$ \\
\hline 44 & 3 & 2 \\
\hline 42 & 2 & 0.5 \\
\hline 41 & 2 & 0.5 \\
\hline 40 & 5 & 10 \\
\hline 39 & 3 & 2 \\
\hline 38 & 2 & 0.5 \\
\hline Total & 17 & 15.5 \\
\hline \multicolumn{2}{|l}{} \\
\hline
\end{tabular}

The values for $\sum \mathrm{Tx}$ are known so $\sum \mathrm{X} 2$ can be calculated as follows:

$$
\begin{aligned}
& \sum X^{2}=\frac{20^{3}-20}{12}-15.5 \\
& \sum X^{2}=665-15.5 \\
& \sum X^{2}=649.5
\end{aligned}
$$

\begin{tabular}{|c|c|c|}
\hline $\begin{array}{c}\text { Var X scores are } \\
\text { twins }\end{array}$ & $\begin{array}{l}\text { Number of Var X } \\
\text { scores for twins }(t)\end{array}$ & $T_{x}=\frac{t^{3}-t}{12}$ \\
\hline 41 & 2 & 0.5 \\
\hline 40 & 3 & 2 \\
\hline 39 & 2 & 0.5 \\
\hline 38 & 4 & 5 \\
\hline 37 & 2 & 0.5 \\
\hline Total & 13 & 8.5 \\
\hline \multicolumn{3}{|c|}{$\begin{array}{l}\text { Source: answers to questionnaires from respondents (processed } \mathrm{b} \\
\frac{2 \mathrm{O}^{3}-2 \mathrm{O}}{12}-8.5 \\
=665-8.5\end{array}$} \\
\hline
\end{tabular}

To calculate $\sum \mathrm{Y} 2$, count hTy first as shown in table 5 the following:

TABLE V. VARIABLE Y SCORE FOR TWINS

So rs can be calculated in the following way:

$$
\begin{aligned}
& r_{s}=\frac{\sum X^{2}+\sum Y^{2}+\sum d i^{2}}{\sqrt[2]{\sum X^{2} \sum Y^{2}}} \\
& r_{s}=\frac{649.5+656.5+632}{\sqrt[2]{649.5 \times 656.5}} \\
& r_{s}=\frac{674}{1305.98}
\end{aligned}
$$

$r_{s}=0.5160$ number 0.5160 give an indication that the relationship between just in time and the cost efficiency of raw material inventories is moderate and positive. 


\section{CONCLUSION}

\section{E. Test of Significance}

Next to calculate the significance of the relationship, the statistical test is used to find the tcount as follows:

$$
\begin{aligned}
& t=\frac{r s \sqrt{n-2}}{1-r_{s}{ }^{2}} \\
& t=\frac{0.5160 \sqrt{20-2}}{1-(0.5160)^{2}} \\
& t=\frac{2.1892}{0.8566} \\
& t=2.5556
\end{aligned}
$$

The tcount with the degree of freedom of $(\mathrm{N}-2)=18 \alpha=$ 0.05 is 1.734 . This shows that tcount $>$ ttable is $2.5556>1.734$. This shows that $\mathrm{H} 0$ was rejected. So there is a significant relationship between just in time with the cost efficiency of raw material inventory, consider the following figure 1 :

(Regional Reception and Rejection Ho)

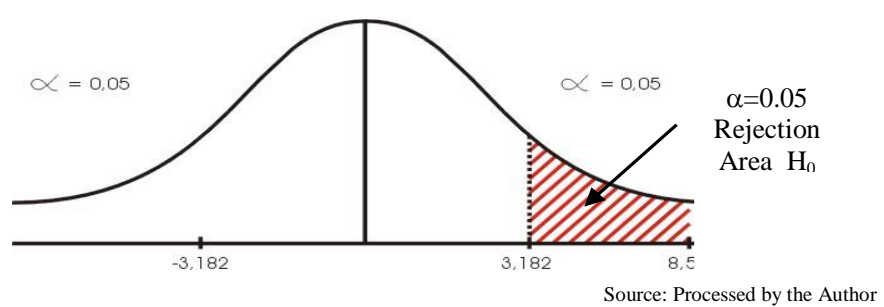

Fig. 1. Normal distribution.

\section{F. Analysis of the Coefficient of Determination}

To find out the magnitude of the contribution of the variable $\mathrm{X}$ (just in time method) to the $\mathrm{Y}$ variable (the cost of raw material inventory) or the coefficient of determination is calculated by the following formula:

$$
\begin{aligned}
\mathrm{Kd} & =\mathrm{r}_{\mathrm{s}}^{2} \times 100 \% \\
\mathrm{Kd} & =0.5160^{2} \times 100 \% \\
\mathrm{Kd} & =0.2662^{2} \times 100 \% \\
\mathrm{Kd} & =26.62 \%
\end{aligned}
$$

From the results of these calculations, shows that $26.62 \%$ changes in the efficiency of raw material inventory can be influenced by the use of the just in time method. And the remaining $73.38 \%$ is influenced by other factors.
Based on the research conducted by the author to the discussion, the writer can conclude that:

- Implementation of the just in time method at PT. Suzuki Indomobil Motor Die Casting Division has done quite well based on the principles and characteristics of just in time. Where companies always improve the system just in time by forming a section that is tasked with fixing and socializing just in time so that this system can be run in the company as perfectly as possible, and can increase efficiency in every production activity, especially creating cost efficiency of raw material inventory. Which aims to increase the competitiveness of companies in competition with both domestic and foreign companies.

- Overall cost efficiency of raw material inventory at PT. Suzuki Indomobil Motor Die Casting division has done quite well. Besides that the characteristics of the just in time method have also been done well, namely: creating a close relationship with the suppliers of raw materials and the sender, sharing information with suppliers, purchasing in small quantities that are produce minimal inventory levels, eliminate uncertainty in supply distribution, and produce high quality production.

The results of statistical analysis regarding the role of the just in time method in supporting the cost efficiency of raw material inventories, shows the correlation coefficient of 0.5160 . this means that the significant test between the two variables shows that tcount is as big as 2.5556 and ttable is 1.734 , so thus h0 is rejected, meaning that there is a significant relationship between the just in time method in the efficiency of raw material inventory costs. The coefficient of determination $(\mathrm{kd})=26.62 \%$, which means that changes in achieving the cost efficiency of raw material inventories can be shown by the just in time method of $26.62 \%$ and the remaining $73.38 \%$ is indicated by changes influenced by other factors.

\section{REFERENCES}

[1] Heizer, Jay, Render, Barry, Operation Management, Ninth edition, New Jersey: Pearson Education, 2008.

[2] F. Zulfikariza, Manajemen persediaan, Cetakan Pertama, Malang: UMM, 2005.

[3] Sugiyono, Metode Penelitian Kuantitatif Kualitatif dan R\&D, Bandung, Alfabeta, 2004.

[4] Sugiyono, Metode Penelitian Bisnis, Cetakan Keduabelas. Bandung, Alfabeta, 2005 